UDC 811.111.161.2'25

DOI https://doi.org/10.32447/2663-340X-2021-9.6

\title{
POETIC ANALYSIS OF SPEECH CHARACTERISTIC OF MENTALY RETARDATED PERSONALITY
}

\author{
Bundza Olha Ihorivna \\ MA student of English Philology Department \\ Faculty of Foreign Languages \\ Lviv Franko National University \\ Str. Universytetska, 1, Lviv, Ukraine
}

\begin{abstract}
The article deals with the investigation of characters' speech in a literary text as the main constructive component of the image of the character. In modern literary studies, it has different vectors of analysis, but most often speech characteristics of characters are presented as one of the aspects of image creation. In linguistics, the subject of study is based on the material of oral speech and texts which represent general, typological and specific features of communication, speech etiquette, or speech peculiarities of different social groups. In the process of creation verbal representation of the image of a character occupies a significant place. Modern writers use deliberate errors as a kind of language game that helps to draw the reader's attention to the author's intentions. The purpose of the research is to study the main character's complex identity due to his mental retardation based on the novel "Flowers for Algernon" by D. Keyes, focusing on lingual, moral and emotional components. The realization of this aim requires the fulfilment of the following tasks: 1) to define the key features of the character's speech in the novel "Flowers for Algernon" by D Keyes; 2) to single out dominant stylistic devices and expressive means at different language levels - graphic, phonetic, lexical and syntactic, which reveals the main's character mental retardation. The object of our investigation is also to analyze through the prism of poetics numerous grammar errors as means of language play. The novel understudy has a form of a diary report (first-person narrative), and this made it possible to use psychological analysis of his inner world and the description of his intellectual and emotional worlds. All of them are determined by graphon, the main stylistic device in the novel. Special poetic analysis of speech characteristic of mental retarded personality becomes especially actual, especially when eliciting the novel by Daniel Keyes "Flowers for Algernon".
\end{abstract}

Key words: speech characteristics, mental retarded personality, poetic analysis.

Problem statement and its relevance. The study of characters' speech in a work of art as the main constructive component of the image of the character in its characteristic function has in modern philological science different vectors of analysis $[4,5]$. Contemporary literary studies present speech characteristics of characters as one of the aspects of image creation in literary texts of different genres [8; 9]. In linguistics, the subject of study is based on the material of oral speech and texts which present general, typological and specific features of communication [2], the subtleties of speech etiquette, the specifics of speech of different social groups $[4 ; 5 ; 7]$ and so on. Special poetic analysis of speech characteristic of mental retarded personality becomes especially actual when eliciting the novel by Daniel Keys "Flowers for Algernon". It's interesting to mention that Daniel Keys is an American prose writer, a scientist-philologist and a bachelor of psychology. That's why in the analysed novel the author also touches on the problems of morality, ethics, and, even, the theological aspects. Fantastic at first glance, the plot of the novel, written in 1966, nowadays takes the form of a socio-psychological drama, where there is a shift of interest from science towards moral and ethical issues, which, given the latest scientific discoveries in the field of DNA and cloning, are becoming increasingly more relevant.

It is worth mentioning that the novel "Flowers for Algernon" is the most famous work by Daniel Keyes. Nevertheless, it cannot be said that its fame is widespread and the story is well known to the whole world. This is the story of Charlie Gordon, a patient with oligophrenia (mentally retarded), whose intelligence as a result of a scientific experiment was brought to a degree of genius, after which he returned just as abruptly to the previous level. It should be noted that the operation of the theme of deviations of human ontogenesis in literature and the existence of research on this phenomenon in the field of psycholinguistics is a consequence of the general democratization of all components of living society. It is also an indicator of freedom of humanitarian thought and the spiritual culture of a society tolerant to the existence of alternative personal expression [6].

It is no doubt, that the author was familiar with specialized literature dealing with mental deviations and the social response to this problem. But 
it was mostly his personal experience that inspired Keyes with the idea of his future book.

Purpose of the article and tasks. The purpose of the research is to study the main character's identity in the novel "Flowers for Algernon" by D Keyes focusing on its lingual, moral and emotional components. The realization of the aim requires the fulfilment of the following tasks: 1) to define the key features of the character's speech in the novel "Flowers for Algernon" by D Keyes; 2) to single out dominant stylistic devices and expressive means at different language levels - graphic, phonetic, lexical and syntactic, which reveals the main's character mental retardation.

Analysis of the latest investigations and publications. In the works of Ukrainian researchers such as I. Bilodid, S. Bibyk, S. Yermolenko, G. Suta language portrait is considered in the context of the study of language personality, combining physical, psychological and social human traits. It is defined as a set of pictorial and expressive means distinguishing one character from others. Human language activity is understood as a definite manner of speech, used vocabulary, intonation, rhetorical tricks, and gestures, which together create a certain image of this person in the environment. This image often is denoted by the term "language passport of the individual" [7, p. 41-43]. Close to this concept is the definition of linguistic personality, which, following Yu. Karaulov, we understand as "a set of abilities and characteristics of a person, who determine the creation and perception of linguistic works (texts), which differ in the degree of structural and linguistic complexity, depth and accuracy reflection of reality, a certain target orientation" $[2$, p. 58]. In the language model personality, this researcher distinguishes three levels: verbal-semantic, linguo cognitive and motivational. The verbal-semantic level is zero, and the intellectual characteristics of the linguistic personality come to the fore, which is relevant in the context of our intelligence. Attention is paid to the ability to properly use verbal means, respectively to the norms of social differentiation [5] and variability.

This phenomenon is closely connected with the notion of language deviations, or in other words language anomalies. N. Arutyunova outlined the problem of anomalies in a language in its entirety: "to mark the sequence of deviations from the norm, which originates in the sphere the perception of the world that supplies data for communication passes through the realm of communication is postponed in lexical, word-forming and syntactic semantics and ends in verbal creativity" $[1$, p. 8$]$.

In the process of creating a verbal and artistic image of a character, a significant place for modern writers is given to artificial, deliberate errors as a kind of language game that helps to draw the reader's attention to the expression of the author's intentions and to which it is given considerable attention in modern linguistic research [2]. The object of our investigation is also the grammar of errors, but not as a means of language play, but as a basic creation of an artistic image due to the peculiarities of the character's speech. In this case, the errors become significant for the recipient (reader, translator) information capacity [5]. It is worth mentioning that the main causes of the emergence of linguistic and communicative deviations are ignorance of the codified norms of literary language, due to the level of the intellectual development of man.

To help the recipient correctly interpret the meaning of language units in the studied novel, we describe the extra lingual situational context of the events depicted in this literary work. The novel understudy has a form of a diary-report (first-person narrative), and this made it possible for the author used for psychological analysis of the inner world of the character and the description of his intellectual and emotional worlds of the inner speech of the character, which are determined by the leading stylistic means and devices.

Results and discussion. The main plotline of the novel can be presented as follows: the main character, Charlie Gordon, has an IQ of 68 . He works as a cleaner in a bakery and attends a night school for mentally retarded adults and tries his best to learn how to read and write. His teacher, a young woman, thinks that he is highly motivated and recommends him to the survey institute for an experiment. Two scientists from that institute are working to increase the intellect of a white mouse, Algernon.

Although the author uses the fantastic element of the experiment, to give momentum to the story, he does not emphasize it. In the first instance, Keyes deals with the substantial problems of the real world. At the same time, without it, the whole plot of the book would not have been possible. At first, the main character even envies the mouse because it is smarter than him and so decides to go through with the experiment: "... I hate that mouse. He always beets me... I never knew before that I was dumber than a mouse... Maybe someday IIl beat Algernon" (2, p. 13).

After the operation, Charlie's intellect starts to grow rapidly. Step by step, he remembers his childhood and adolescence. He was stigmatized by his mother, sister and by his classmates. His mother beat him for not being "normal". His sister used this situation and blamed Charlie for her own mistakes in front of their parents. His classmates 
used his naivety to use him as the "fall guy". He also understands that his colleagues at work were laughing at him and used him as he did not understand what was happening [10].

To my deep consideration, Keyes on purpose makes stylistic, grammatical and punctuation errors in the text of Charlie Gordon's diary to show the underdevelopment of the character, which is expressed through a special selection of language tools: "Gimpy hollered at me because I droppd a tray full of rolles I was carrying over to the oven. They got derty and he had to wipe them off before he put them in to bake. Gimpy hollers at me all the time when I do something rong, but he reely likes me because hes my frend. Boy if I get smart wont he be serprised" (2, p. 8).

Gradually his intellect grows and Charlie learns not only how to read, he learns many foreign languages; he reads scientific articles in Hindi, Japanese, Chinese and Russian. He studies other disciplines as well: physics, biology, chemistry, history. He finds himself in love with his former teacher and tries to start a relationship with her. He is not very successful though, as she thinks that he has become arrogant. She is partly right, as Charlie's character develops together with his intellect. $\mathrm{He}$ reaches his peak - IQ 200, so he becomes significantly cleverer, than his "creators" who maintained the operation [10].

Such great smartness is another aspect that differs the novel "Flowers for Algernon" from other works on the theme of mental retardation. Keyes explored the opposite side of mental retardation an abnormally high IQ. The character conflicts with society and, at the same time, he is in opposition with the emotional side of himself.

Approximately at the same moment that he reaches the highest peak of his IQ Charlie discovers that regression is inevitable. The novel "Flowers for Algernon" is written in the form of the main character's reports to the institute. Charlie also carefully records his regression in the diary: "I'm forgetting things I learned recently. It seems to be following the classic pattern, the last things learned are first things forgotten. <..> Reread my paper on the Algernon-Gordon Effect and even though I know I wrote it, I keep feeling it was written by someone else. Most of it I don't even understand" ( 2 , p. 206).

That is the climax of the story: over time his IQ is going to become the same or even lower than it was before the operation. Charlie leaves the institute and tries to lead an independent life in a rented flat. He takes Algernon with him. At the same time, he continues his research, looking for a way how to stop his regression. Not finding the answer, he contacts his family which left him long ago. He spends his last months before the regression completes with his former teacher, Alice. At the very end of the book, he leaves the city, heading to the asylum and hopes that someone will put flowers on Algernon's grave [10].

Returning to the poetic analysis of speech characteristics of the main character it is necessary to mention that the ontogenesis of the character's speech becomes decisive for the transmission of the process of increasing the level of his IQ and, accordingly, the socialization of his personality. The only desire of the main character of the novel is to become smart, like his friends-bakers, to read smartbooks and to understand what people are saying: "I coud go back to show the guys at the bakery how smart I am and talk with them about things and maybe even get to be an assistin baker" $(2$, p. 13).

Keyes tries to imitate not only a mentally disordered person's way of thinking but his speech characteristics as well, using graphon which became the dominant stylistic means in this novel. By the way, graphon we understand as an intentional violation of the graphical shape of a word (or word combination) used to reflect its pronunciation $[4,23]$. The author uses a variety of different kinds of graphons to make Charlie's writing look more authentic. The first extract is taken from the first report of the main character. At this point in time, Charlie's IQ is 68: "Dr Strauss says I shoud rite down what I think and remembir and evrey thing that happins to me from now on. I dont no why but he says its importint so they will see if they can use me. I hope they use me becaus Miss Kinnian says mabye they can make me smart. I want to be smart. I am 32 yeres old and next munth is my brithday. I tolld dr Strauss and perfesser Nemur I cant rite good but he says it dont matter he says I shud rite just like I talk and like I rite compushishens in Miss Kinnians class at the beekmin collidge center for retarted adults where I go to lern 3 times a week on my time off' $(1,1)$.

It can be seen clearly that Charlie has difficulties with spelling which is expressed by various graphons [5, 24]. His orthography is phonemic, which means that the graphemes correspond to the phonemes of the language. For example, in the words "shoud" and "rite" the silent consonants are missing. In the first instance, it is silent $/ 1 /$, in the second one it is silent/w/. In the word "becaus" silent vowel /e/ is missing. There are not many morphological errors in the extract, as this type of error implies the wrong structure of the word. Among them can be mentioned "tolld", as the past tense is formed with a mistake.

In general, it can be said that at that point Charlie is in command only of the Present Simple tense. 
He uses it a bit awkwardly but almost without mistakes, except for the phrase "it dont matter". Another example shows such syntactic mistake as a double negation: "I told them I dont want to race with Algernon no more." (2, p. 16). The second extract is taken from the 7th report. It was written 18 days after Charlie's operation: "I didnt know I was thinking and remembering. Maybe that means something is happining to me. I dont feel different but Im so exited I cant sleep" (1, p. 23). As we can see from this textual fragment the character still has difficulties with spelling. The punctuation is lacking and the sentences are still short and unextended. Nevertheless, he begins to use other tenses, such as the present and the past continuous which was not customary for him before the operation.

The next extract is taken from the 9th report when Charlie is not a genius yet, but his IQ is close to the IQ of an average person of his age: "Prof. Nemur gave me some more tapes to play while I sleep. I still don't know how the conscious and unconscious mind works, but Dr Strauss says not to worry yet" $(1$, p. 34$)$. The above paragraph proves that after Charlie's surgery, there are significant changes already with his ability to read a page in seconds and operate with complex terms, and in general with his emotional development as a person: "I have often reread my early progress reports and seen the illiteracy, the childish naivete, the mind of low intelligence peering from a dark room, through the keyhole, at the dazzling light outside" (2, p. 139). As you can see above, there are no more spelling mistakes. Sentences are longer, the second one in the extract above is a compound sentence. Also, Charlie begins to use punctuation properly.

It is logical that along with the decreasing of Charlie's IQ his style of writing becomes primitive again. If we project the level of the intellectual development of Charlie on the position of transactional analysis of the American psychologist Eric Bern [3], then before the experiment, the character is in the guise of "Child" (one of three guises status-role interaction of people, along with "Adult" and "Father"). The child, according to E. Bern, is a source of mental energy of the individual - our desires, inclinations, feelings (cheerfulness, curiosity, looseness, insecurity, trust, insecurity, joy, curiosity, fears, etc).

After the operation, Charlie appears in the guise of "Adult" - the bearer of a rational principle, responsible for unbiased analysis of any vital information. As a result, the choice changes the author of the text of the speech strategy - speech reactions this ego-state carries with it appeals to common sense). Thus, in the text of the novel under study, the author first chooses for narration in the diary of Charlie Gordon description and its characteristic lexical and syntactic devices, which after changes the character is replaced in the texts of his reports by a reflection that corresponds to the form abstract thinking. The dominant type of logical-syntactic relations, in this case, are causal relationships, which are not always presented explicitly and require additional decoding [5].

So, most often in speech characteristics of Charlie Gordon, until he reached a high level of mental development, there are markers of speech deviations at the phonographic level. Indicative of the use, in particular, of the graphone as a defining stylistic device is the text of the first report in Charlie's diary: "Progris report 1 martch 3. Dr Strauss says I shoud rite down what I think and remembir and evrey thing that happins to me from now on. I dont no why but he says its importint so they will see if they can use me" $(2$, p. 1$)$.

Unfamiliar with the correct spelling of words, Charlie mostly uses the phonetic principle to create his entries in the diary, therefore, in particular, the author omits the so-called dumb letters in writing words, and in cases where two letters convey one sound, uses one. For example, we meet in his texts writing: shud (correctly should); rite (write); faled (failed); pockit (pocket); happind (happened); acheve (archives); intellect (intellect); operation (operation); nuthing (nothing); pepul (pupil); dint (didn't); becaus (because); laffed (laughed); practice (practice); lerned (learned); memory (memory); bandages; recommended (recommended); perminint (permanent) [5].

Another graphic technique observed here is: previously unknown long, difficult to write words Charlie presents specially: "He said Harold thats Prof Nemurs frist name I know Charlie is not what you had in mind as the frist of your new breed of intelek ** (coudnt get the word) superman. But most people of his low ment $* *$ are host $* *$ and uncoop ** they are usally dull and apathet $* *$ and hard to reach" ( 2, p. 7). Later, Charlie reflects on the pages of the diary: "Miss Kinnian teeches me how to spel better. $<\ldots>$ I have lots of truble with through that you say threw and enough and tough that you dont say enew and tew. You got to say enuff and tuff. Thats how I use to rite it before I started to get smart ». And then: "Everybody on the floor came around and they were laff laughing and Frank Reilly said yes Charlie you have been here long enuff enough" (2, p. 24).

Considering lexical stylistic devices and phraseological units used in the character's speech, we find the predominance of colloquial, informal, style and vernacular: "Boy woud they'be serprised to see me smart..." (2, p. 9); "Fancy things I bet" (2, p. 12). 
Soon after Charlie's IQ reaches its peak: in June he writes in his 11th report the following: "The same thing happened when I tried to discuss Chaucer with an American literature specialist, questioned an Orientalist about the Trobriand Islanders, and tried to focus on the problems of automation caused unemployment with a social psychologist who specialized in public opinion polls on adolescent behavior" (1, p. 69).

"I was able to finish my linguistic analysis of Urdu verb forms and send the paper to the International Linguistics Bulletin. It will send the linguists back to India with their tape recorders, because it undermines the critical superstructure of their methodology. I can't help but admire the structural linguists who have carved out for themselves a linguistic discipline based on the deterioration of written communication. Another case of men devoting their lives to studying more and more about less and less - filling volumes and libraries with the subtle linguistic analysis of the grunt. Nothing wrong with that, but it should not be used as an excuse to destroy the stability of language"
(2, p. 148). The last example shows the manifestation of the author's philological education and his views on the urgent problems of linguistics, namely, some peculiarities of language changes.

He uses not only longer sentences, but longer words and special terms as well to express his thoughts. There are simple, compound and complex sentences in his reports. No more morphological or syntactic mistakes can be found in the extract. Also, there are no spelling errors in his text. Charlie even begins to use slang and argotic expressions: "God damn him. He didn't know what he was talking about." (1, p. 113).

Conclusion. It is proved that stylistic devices used to describe the way of thinking of a retarded person and his speech characteristics can be traced at all language levels: phonetic, graphic, lexical and syntactical. It is an unusual experience for the reader to get acquainted with the inner thoughts of the person with a quite low or high IQ. It is defined that graphon is the key stylistic device used to describe the main features of the character's speech in the novel "Flowers for Algernon" by D Keyes.

\section{BIBLIOGRAPHY}

1. Арутюнова Н. Д. Аномалии и язык (К проблеме языковой «картины мира»). Вопросы языкознания. 1987. № 3. C. 3-19

2. Бацевич Ф. С. Основи комунікативної девіатології. Львів: ЛНУ імені І. Франка, 2000. 236 с.

3. Берн Э. Игры, в которые играют люди: психология человеческих отношений. Люди, которые играют в игры: психология человеческой судьбы: пер. с англ. Москва: Университетская книга, 1998. 398 с.

4. Кухаренко В.А. Практикум з стилістики англійської мови: Підручник. - Вінниця. «Нова книга», 2000. 160 с.

5. Лисиченко Т. Ю. Мовленнєвий паспорт особистості як основа творення художнього образу: граматика та поетика помилок. Лінгвістичні дослідження: Зб. наук. праць ХНПУ ім. Г.С. Сковороди. 2017. Вип. 46, 107 -118с.

6. Ставицька Л. Арго, жаргон, сленг: соціальна диференціація української мови. Київ: Критика, 2005. 464 с.

7. Стернин И. А. Введение в речевое воздействие. Воронеж, 2001. 252 с.

8. Babelyuk O., Aleksandruk I. Conceptual Category Person and Means of its Verbal Presentation in the Fantasy Genre. Advanced Education, 10, 2018, P. 158-165. DOI: 10.20535/2410-8286.142802

9. Babelyuk O., Galaidin A. The image of wise woman in a literary text (based on the novel (The devil wears Prada" by Lauren Weisberger). Scientific Journal of Polonia University. 37, 2019 (6). P. 63-70. DOI: http://dx.doi.org/10.23856/3706 https://nuife.org/index.php/pnap/article/view/268/247

INTERNET SOURCES

10. file:///C:/Users/admin/Downloads/BPTX_2013_2_11410_0_351949_0_142135.pdf

\section{ILLUSTRATIVE SOURCES}

1. Keyes, Daniel. Flowers for Algernon. London: Orion Publishing Group, 2002. 216. Print.

2. Keyes Daniel. Flowers for Algernon. Bantam Books. 1975. 221 p.

\section{REFERENCES}

1. Arutiunova, N. D. (1987). Anomalyy y yazyk (K probleme yazykovoi «kartyny myra»). Voprosy yazykoznanyia, 3. S. 3-19

2. Batsevych, F. S. (2000). Osnovy komunikatyvnoi deviatolohii. Lviv: LNU imeni I. Franka. $236 \mathrm{s.}$

3. Bern, Э. (1998). Yhry, v kotorye yhraiut liudy: psykholohyia chelovecheskykh otnoshenyi. Liudy, kotorye yhraiut v yhry: psykholohyia chelovecheskoi sudby: per. s anhl. Moskva: Unyversytetskaia knyha. 398 s.

4. Kukharenko, V.A. (2000). Praktykum z stylistyky anhliiskoi movy: Pidruchnyk. Vinnytsia. «Nova knyha». 160 s. 
5. Lysychenko, T. Yu. (2017). Movlennievyi pasport osobystosti yak osnova tvorennia khudozhnoho obrazu: hramatyka ta poetyka pomylok. Linhvistychni doslidzhennia: Zb. nauk. prats KhNPU im. H.S. Skovorody. 2017. Vyp. 46, 107-118s.

6. Stavytska L. Arho, zharhon, slenh: sotsialna dyferentsiatsiia ukrainskoi movy. Kyiv: Krytyka, 2005.464 s.

7. Sternyn Y. A. Vvedenye v rechevoe vozdeistvye. Voronezh, 2001. $252 \mathrm{~s}$.

8. Babelyuk O., Aleksandruk I. Conceptual Category Person and Means of its Verbal Presentation in the Fantasy Genre. Advanced Education, 10, 2018, P. 158-165. DOI: 10.20535/2410-8286.142802

9. Babelyuk O., Galaidin A. The image of wise woman in a literary text (based on the novel ,The devil wears Prada" by Lauren Weisberger). Scientific Journal of Polonia University. 37, 2019 (6). P. 63-70. DOI: http://dx.doi. org/10.23856/3706 https://nuife.org/index.php/pnap/article/view/268/247

\title{
ПОЕТИЧНИЙ АНАЛІЗ МОВЛЕНЕВИХ ХАРАКТЕРИСТИК ОСОБИ 3 МЕНТАЛЬНИМИ ПОРУШЕННЯМИ
}

\author{
Бундза Ольга Ігорівна \\ магістрантка кафедри англійської філологї, \\ факультету іноземних мов \\ Львівського національного університету імені Івана Франка \\ вул. Університетська 1, Львів, Україна
}

\begin{abstract}
Статтю присвячено дослідженню мови персонажа у художньому творі як основної конструктивної складової образу персонажа крізь призму лінгвопоетики. У сучасній філологічній науці представлено різні вектори аналізу мовленнєвих характеристик персонажів. У лінгвістиці предметом дослідження є усне мовлення та тексти, щзо відображають загальні, типологічні чи специфічні особливості спілкування, тонкощі мовленнєвого етикету, специфіку мовлення різних соціальних груп. У процесі створення словесно-художнього образу персонажа значне місие для сучасних письменників відводиться штучним, навмисним помилкам якрізновиду мовноїгри, щзо допомагає привернути увагу читача до вираження авторських намірів. Мета дослідження - вивчити складну особистість головного героя через його ментальні порушення на матеріалі роману Д. Кіза «Квіти для Елджернона», зосередившись на його мовній, моральній та емоційній складових. Реалізація мети вимагає виконання таких завдань: 1) визначити основні риси мовлення персонажа в романі Д. Кейса «Квіти для Елджернона»; 2) виділити домінуючі стилістичні прийоми та засоби на різних мовних рівнях - графічному, фонетичному, лексичному та синтаксичному, щзо виявляє розумову відсталість персонажа. У роботі доведено, шоо досліджуваний роман має форму щзоденника (розповідь від першої особи), а провідним стилістичних засобом відтворення мови персонажа 3 розумовими відхиленнями є різного роду графони. Важливим також вважаємо використання для психологічного аналізу внутрішнього світу персонажа, опис його інтелектуального та емоиійного станів, які визначаються провідними стилістичними засобами та прийомами $і$ графоном у тому числі. Спеціальний поетичний аналіз мовлення персонажа, характерний для розумово відсталої особистості, стає особливо актуальним, під час інтерпретації роману Даніеля Кіза «Квіти для Елджернона».

Ключові слова:поетичний аналіз, розумово відстала особистість графон.
\end{abstract}

